\title{
SISTEM PENDUKUNG KEPUTUSAN PENERIMAAN PEGAWAI BARU PT.PLN (PERSERO) KANTOR PUSAT DENGAN MENGGUNAKAN METODE SIMPLE ADDITIVE WEIGHTING (SAW)
}

\author{
Yasni Djamain $^{1}$, Herlinda De Christin ${ }^{2}$ \\ ${ }^{1,2}$ Jurusan Teknik Informatika Sekolah Tinggi Teknik PLN Jakarta \\ 1yasnidj@yahoo.com, 2dinda.loho@yahoo.com
}

\begin{abstract}
ABSTRAK
PT.PLN (Persero) adalah perusahaan milik negara terbesar di Indonesia yang menangani pelayanan tenaga listrik seluruh wilayah di Indonesia dan berkantor pusat di Jakarta. Untuk mendukung pertumbuhan progresif dan membangun kemampuan organisasi, PT PLN (Persero) dalam melayani masyarakat dibutuhkan sumber daya manusia yang berkualitas.Dalam hal ini perlu dibangun sebuah sistem pendukung keputusan untuk membantu dalam menyeleksi dan menetapkan pegawai yang berbasis PT.PLN (Persero).Salah satu model yang dapat digunakan untuk sistem pendukung keputusan adalah model Multiple Attribute Decision Making (MADM) dengan metode Simple Additive Weighting (SAW). Metode ini dipilih karena metode ini menentukan nilai bobot untuk setiap atribut, kemudian dilanjutkan dengan proses perankingan yang akan menyeleksi alternatif terbaik. Penelitian dilakukan dengan mencari nilai bobot untuk setiap kriteria, dan kemudian membuat proses peringkat yang akan menentukan alternatif yang optimal adalah pelamar terbaik. Hasil dari aplikasi sistem pendukung keputusan ini adalah terpilihnya alternatif terbaik pelamar yang berhak diterima menjadi pegawai karena lulus seleksi secara terurut sesuai perankingan dengan menggunakan bahasa pemrograman PHP.
\end{abstract}

Kata Kunci: Sistem Pendukung Keputusan, seleksi , pegawai

\subsection{Latar Belakang}

\section{Pendahuluan}

Pada masa ini teknologi dan informasi sangat berperan penting guna menunjang aktivitas sehari-hari, baik dalam dunia bisnis, hiburan, pendidikan, pemerintahan dan lain sebagainya. Informasi dapat digunakan untuk membantu pengambilan keputusan dalam sistem pendukung keputusan (Decision Support System) mulai dari mengidentifikasi masalah, memilih data yang relevan, dan menentukan pendekatan yang digunakan dalam proses pengambilan keputusan, sampai mengevaluasi pemilihan alternatif, melakukan penilaian, melakukan perubahan kriteria, dan perubahan nilai bobot. Hal ini berguna untuk memudahkan pengambilan keputusan yang terkait dengan masalah penerimaan calon pegawai baru pada PT.PLN(Persero) Kantor Pusat.

Model yang digunakan dalam sistem pendukung keputusan ini adalah Multiple Attribute Decision Making (MADM) dan Metode Simple Additive Weighting (SAW) dipilih karena metode ini menentukan nilai bobot untuk setiap atribut, kemudian dilanjutkan dengan proses perankingan yang akan menyeleksi alternatif terbaik yaitu yang memenuhi syarat untuk diterima menjadi pegawai baru PT.PLN(Persero) berdasarkan kriteria-kriteria yang ditentukan. Dengan metode perangkingan tersebut, diharapkan penilaian akan lebih tepat karena didasarkan pada nilai kriteria dan bobot yang sudah ditentukan sehingga akan mendapatkan hasil yang lebih akurat terhadap calon pegawai baru PT.PLN (Persero) yang diterima.

\subsection{Batasan Masalah}

Berdasarkan latar belakang permasalahan maka masalah yang dirumuskan yaitu:

1. Kriteria yang ditentukan untuk penerimaan calon pegawai baru PT.PLN(Persero) Kantor Pusat.

2. Merancang sebuah sistem pendukung keputusan dengan menggunakan metode Simple Additive Weighting (SAW) untuk menentukan penerimaan calon pegawai baru berdasarkan bobot dan kriteria yang sudah ditentukan.

3. Proses penyeleksian yang dibuat dibatasi pada proses untuk mencari kandidat yang memenuhi persyaratan dengan kriteria yang telah ditentukan.

\subsection{Tujuan}

Tujuan penelitan ini adalah membangun suatu model pengambilan keputusan dengan mengunakan Multiple Attribute Decision Making (MADM) dengan metode Simple Additive Weighting (SAW) untuk menentukan penerimaan pegawai baru berdasarkan bobot dan kriteria yang sudah ditentukan.

\subsection{Identifikasi Masalah}

Masalah yang di rumuskan yaitu bagaimana membuat suatu sistem pendukung keputusan yang dapat membantu membuat keputusan dalam penerimaan pegawai baru pada PT.PLN(Persero) Kantor Pusat berdasarkan hasil analisa sesuai dengan kriteria yang ditentukan. 


\section{LANDASAN TEORI}

Konsep Sistem Pendukung Keputusan (SPK) / Decision Support System (DSS) pertama kali diungkapkan pada awal tahun 1970-an oleh Michael S. Scott Morton dengan istilah Management Decision System. Sistem tersebut adalah suatu sistem yang berbasis komputer yang ditujukan untuk membantu mengambil keputusan dengan memanfaatkan data dan model tertentu untuk memecahkan berbagai persoalan yang tidak terstruktur. Istilah SPK mengacu pada suatu sistem yang memanfaatkan dukungan komputer dalam proses pengambilan keputusan.

SPK dirancang untuk mendukung seluruh tahap pengambilan keputusan mulai dari mengidentifikasi masalah, memilih data yang relevan, dan menentukan pendekatan yang digunakan dalam proses pengambilan keputusan, sampai mengevaluasi pemilihan alternatif. Banyak metode yang dapat digunakan dalam sistem pengambilan keputusan. Salah satu metode tersebut yang digunakan dalam penelitian ini adalah metode Simple Additive Weighting (SAW).

\subsection{Metode Simple Additive Weighting (SAW)}

Metode SAW sering dikenal dengan istilah metode penjumlahan terbobot. Konsep dasar metode SAW adalah mencari penjumlahan terbobot dari rating kinerja pada setiap alternatif pada semua atribut. Metode SAW dapat membantu dalam pengambilan keputusan suatu kasus, akan tetapi perhitungan dengan menggunakan metode SAW ini hanya yang menghasilkan nilai terbesar yang akan terpilih sebagai alternatif yang terbaik. Perhitungan akan sesuai dengan metode ini apabila alternatif yang terpilih memenuhi kriteria yang telah ditentukan. Metode SAW ini lebih efisien karena waktu yang dibutuhkan dalam perhitungan lebih singkat.

Metode SAW membutuhkan proses normalisasi matriks keputusan $(\mathrm{X})$ ke suatu skala yang dapat diperbandingkan dengan semua rating alternatif yang ada.

$$
r_{i j}= \begin{cases}\frac{x_{i j}}{\operatorname{Max}_{i} x_{i j}} & \text { jika } \mathrm{j}=\text { atribut keuntungan (benefit) } \\ \frac{\operatorname{Min}_{i} x_{i j}}{x_{i j}} & \text { jika } \mathrm{j}=\text { atribut biaya (cost) }\end{cases}
$$

dimana rij adalah rating kinerja ternormalisasi dari alternatif Ai pada atribut $\mathrm{Cj} ; \mathrm{i}=1,2, \ldots, \mathrm{m}$ dan $\mathrm{j}=1,2, \ldots, \mathrm{n}$. Nilai preferensi untuk setiap alternatif $(\mathrm{Vi})$ diberikan sebagai:

$$
V_{i}=\sum_{j=1}^{n} w_{j} r_{i j}
$$

Nilai Vi yang lebih besar mengindikasikan bahwa alternatif Ai lebih terpilih.

\subsection{Keuntungan Simple Additive Weighting (SAW)}

Dibawah ini ada beberapa keuntungan Simple Additive Weighting (SAW) menurut (Kusrini, 2007):

1. Simple Additive Weighting (SAW) memberikan suatu model yang mudah dimengerti, luwes untuk bermacam-macam persoalan yang tidak terstruktur.

2. Simple Additive Weighting (SAW) mencerminkan cara berpikir alami untuk memilah-milih elemenelemen dari suatu system ke dalam berbagai tingkat berlainan dan mengelompokan unsur yang serupa dalam setiap tingkat.

3. Simple Additive Weighting (SAW) memberikan suatu skala pengukuran dan memberikan metode untuk menetapkan prioritas.

4. Simple Additive Weighting (SAW) memberikan penilaian terhadap konsistensi logis dari pertimbangan-pertimbangan yang digunakan dalam menentukan prioritas.

5. Simple Additive Weighting (SAW) menuntun ke suatu pandangan menyeluruh terhadap alternatif yang muncul untuk masalah yang dihadapi.

6. Simple Additive Weighting (SAW) memberikan suatu sarana untuk penilaian yang tidak dipaksakan tetapi merupakan penilaian yang sesuai pandangan masing-masing.

7. Simple Additive Weighting (SAW) memungkinkan setiap orang atau kelompok untuk mempertajam kemampuan logic dan intuisinya terhadap persoalan yang dipetakan melalui Simple Additive Weighting (SAW).

\section{METODOLOGI PENELITIAN}

\subsection{Analisis}

\subsubsection{Analisa Sistem Berjalan}

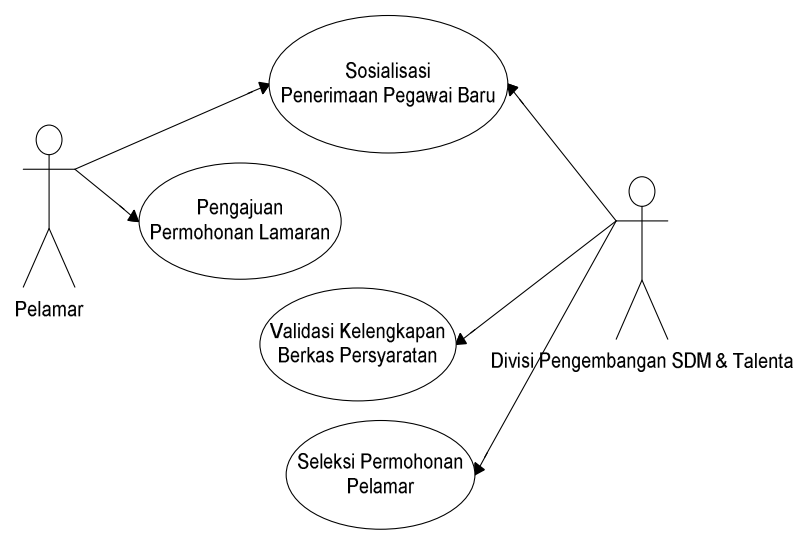

Gambar 3.2 Usecase Diagram yang sedang berjalan 


\subsubsection{Analisis Kebutuhan Sistem}

Kebutuhan informasi pada sistem pendukung keputusan untuk penerimaan pegawai baru PT.PLN (Persero) yang diusulkan adalah kriteria yang dibutuhkan berdasarkan persyaratan penerimaan pegawai PT.PLN (Persero) secara umum yaitu Administrasi, General Aptitude Test (GAT), Akademis dan Bahasa Inggris, Psikotes dan FGD, Kesehatan dan terakhir wawancara. Ada 10 kriteria yang telah ditentukan dalam tahap seleksi wawancara dan selanjutnya penjabaran bobot setiap kriteria yang telah dikonversikan dengan nilai interval untuk mempermudah perhitungan adalah sebagai berikut:

- Kriteria Kedisiplinan (C1)

\begin{tabular}{|c|c|}
\hline Nilai Kedisiplinan & Nilai \\
\hline Hadir $60 \%$ dalam setahun & 2,35 \\
\hline Hadir $70 \%$ dalam setahun & 2,77 \\
\hline Hadir $80 \%$ dalam setahun & 3,20 \\
\hline Hadir $90 \%$ dalam setahun & 3,63 \\
\hline Hadir $100 \%$ dalam setahun & 4,05 \\
\hline
\end{tabular}

- Kriteria Masa Pengalaman Informal / Formal (C2)

\begin{tabular}{|c|c|}
\hline $\begin{array}{c}\text { Nilai Masa Pengalaman } \\
\text { Informal/Formal }(\mathrm{X})\end{array}$ & Nilai \\
\hline $\mathrm{X}<=1$ tahun & 2,2 \\
\hline $\mathrm{X}=1-2$ tahun & 2,6 \\
\hline $\mathrm{X}=2-3$ tahun & 3 \\
\hline $\mathrm{X}=3-5$ tahun & 3,4 \\
\hline $\mathrm{X}>=5$ tahun & 3,8 \\
\hline
\end{tabular}

- Kriteria Ketaatan Dalam Melaksanakan Tugas (C3)

\begin{tabular}{|c|c|}
\hline $\begin{array}{c}\text { Nilai Ketaatan Dalam } \\
\text { Melaksanakan Tugas }\end{array}$ & Nilai \\
\hline Sangat Baik & 2,375 \\
\hline Baik & 2 \\
\hline Cukup & 1,625 \\
\hline
\end{tabular}

- Kriteria Kecakapan (C4)

\begin{tabular}{|c|c|}
\hline Kecakapan & Nilai \\
\hline Sangat Baik & 6,33 \\
\hline Baik & 5,33 \\
\hline Cukup & 4,33 \\
\hline
\end{tabular}

- Kriteria Kepemimpinan (C5)

\begin{tabular}{|c|c|}
\hline Kepemimpinan & Nilai \\
\hline Sangat Baik & 0,80 \\
\hline Baik & 0,66 \\
\hline Cukup & 0,54 \\
\hline
\end{tabular}

- Kriteria Keterampilan (C6)

\begin{tabular}{|c|c|}
\hline Keterampilan & Nilai \\
\hline Sangat Baik & 7,125 \\
\hline Baik & 6 \\
\hline Cukup & 4,875 \\
\hline
\end{tabular}

- Kriteria Hasil Kerja Yang Diperoleh (C7)

\begin{tabular}{|c|c|}
\hline $\begin{array}{c}\text { Nilai Hasil Kerja Yang } \\
\text { Diperoleh }\end{array}$ & Nilai \\
\hline Sangat Baik & 2,77 \\
\hline Baik & 2,33 \\
\hline Cukup & 1,90 \\
\hline
\end{tabular}

- Kriteria Moral dan Perilaku (C8)

\begin{tabular}{|c|c|}
\hline Moral dan Perilaku & Nilai \\
\hline Sangat Baik & 1,58 \\
\hline Baik & 1,33 \\
\hline Cukup & 1,08 \\
\hline
\end{tabular}

- Kriteria Kerjasama (C9)

\begin{tabular}{|c|c|}
\hline Moral dan Perilaku & Nilai \\
\hline Sangat Baik & 1,58 \\
\hline Baik & 1,33 \\
\hline Cukup & 1,08 \\
\hline
\end{tabular}

- Kriteria Kreativitas dan Inovasi (C10)

\begin{tabular}{|c|c|}
\hline Kreativitas dan Inovasi & Nilai \\
\hline Sangat Baik & 5,145 \\
\hline Baik & 4,33 \\
\hline Cukup & 3,521 \\
\hline
\end{tabular}

\subsection{Flowchart Proses}

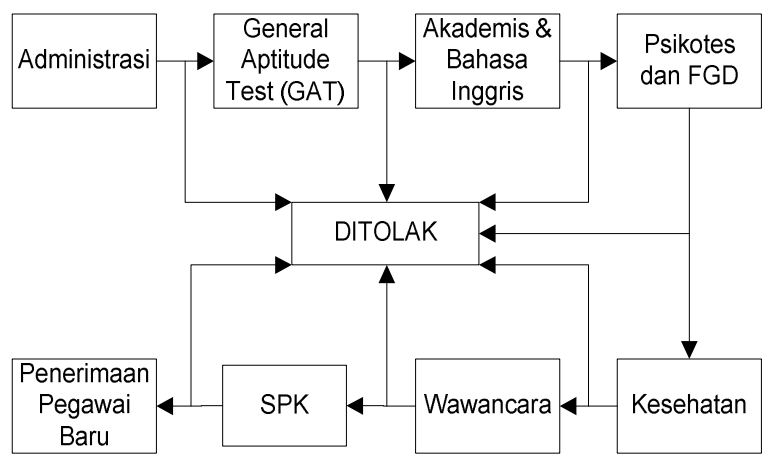

Gambar 3.3 Usecase Diagram usulan 


\section{PERANCANGAN}

4.1 Activity Diagram

a. Activity Diagram untuk pengolahan data

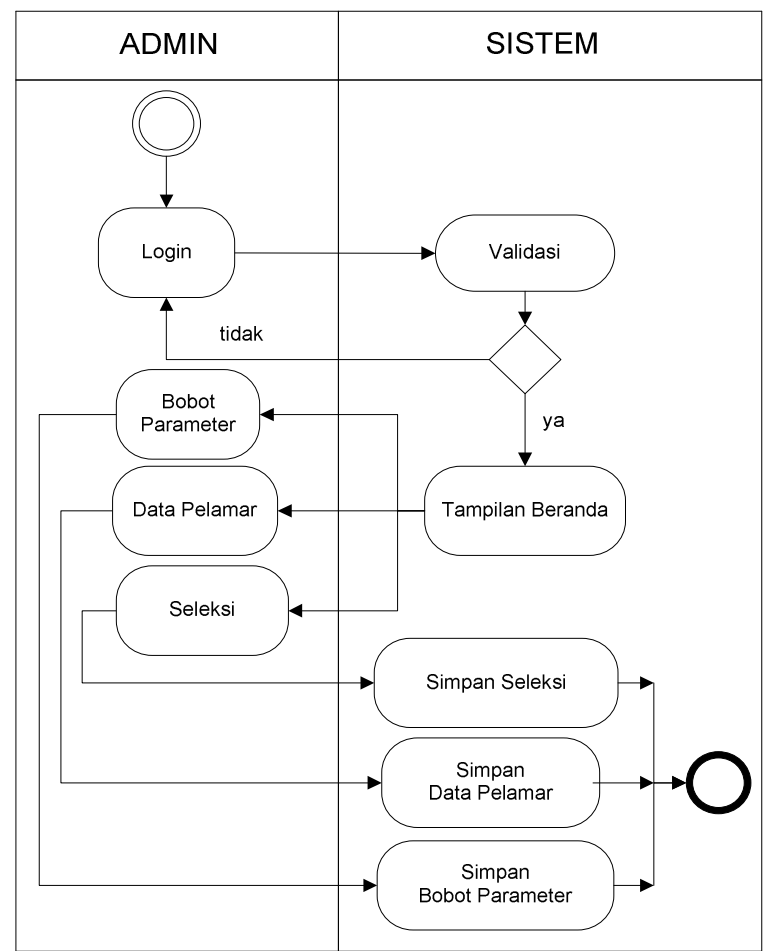

Gambar 3.4 Activity diagram pengolahan data

Pada gambar diatas menunjukkan activity diagram untuk melakukan pengolahan data yang dimulai dengan melakukan proses login, jika username dan password valid maka akan menampilkan halaman utama, kemudian dilakukan pengolahan data bobot parameter, data pelamar dan seleksi yang dilanjutkan dengan penyimpanan data tersebut yang telah diolah.

b. Activity Diagram untuk proses seleksi

Pada gambar dibawah ini menunjukkan proses seleksi yang dilakukan oleh admin (bagian rekrutmen dan seleksi). Aktivitas seleksi ini berdasarkan nilai dengan beberapa kriteria yang kemudian dilakukan perankingan untuk hasil seleksinya, dimana apabila data telah diinput kemudian klik menu seleksi maka sistem akan memproses perhitungan yang akan menampilkan hasil ranking tersebut.

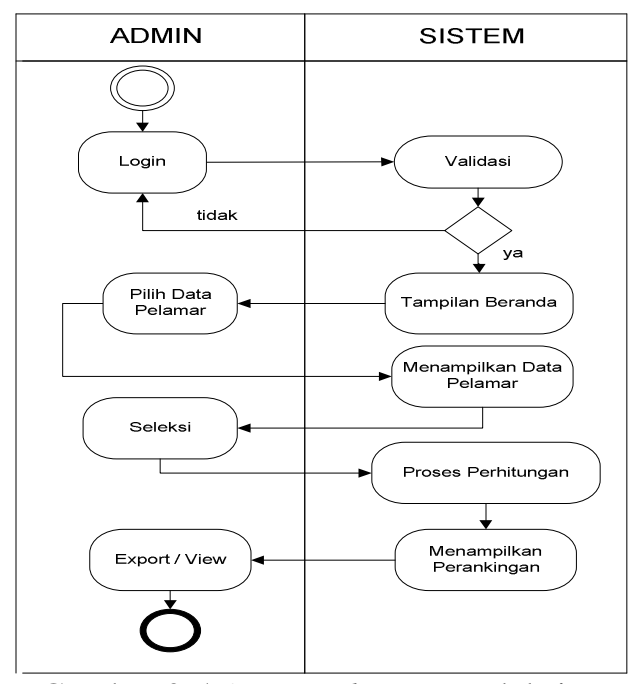

Gambar 3.5 Activity diagram seleksi

\subsection{Use Case Diagram}

Berikut adalah use case diagram untuk sistem pendukung keputusan penerimaan pegawai baru :

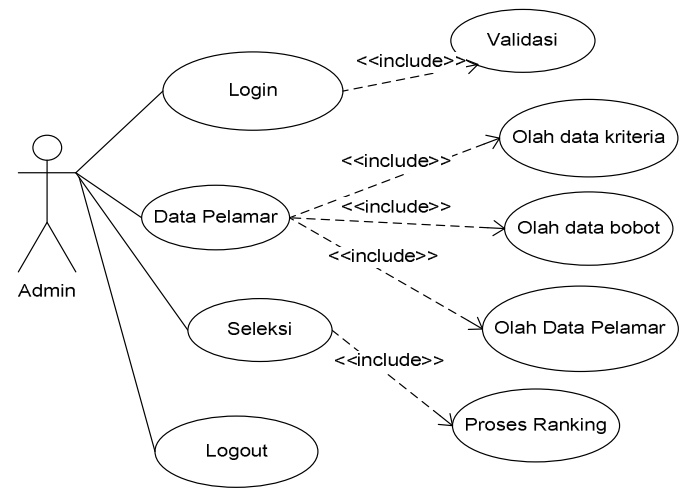

Gambar 3.6 Use case diagram pengolahan data

\subsection{Sequence Diagram}

a. Sequence diagram untuk use case login

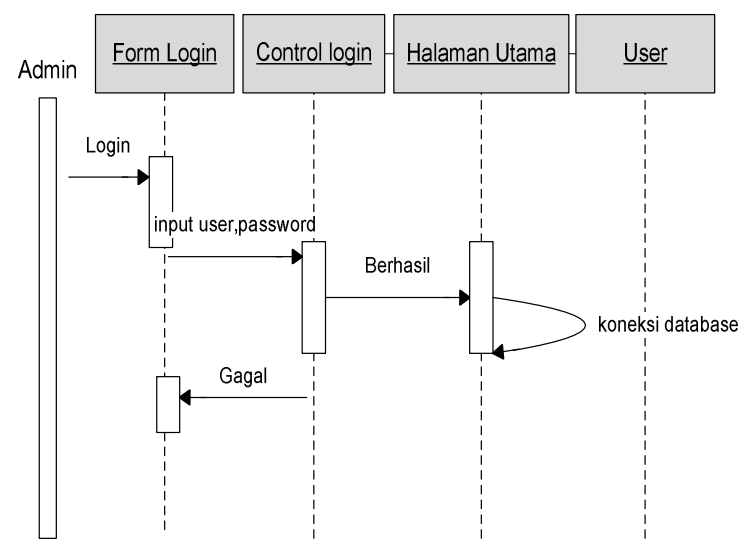

Gambar 3.7 Sequence diagram untuk use case login 
b. Sequence diagram untuk use case data pelamar

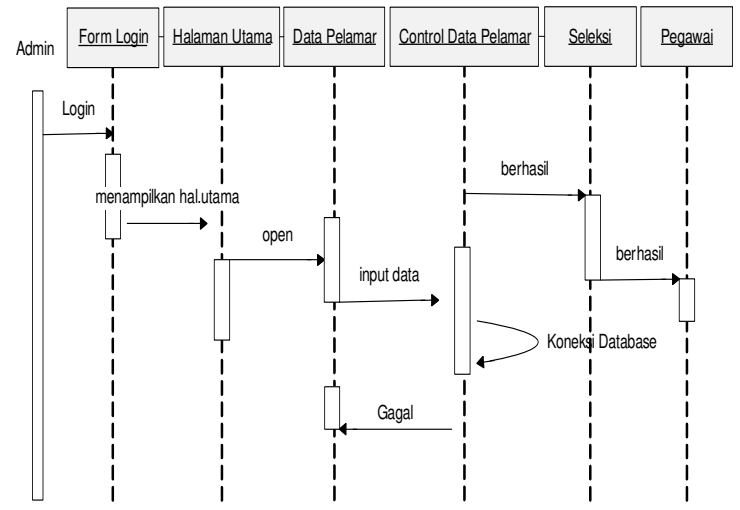

Gambar 3.8 Sequence diagram untuk use case data pelamar

c. Sequence diagram untuk use case seleksi

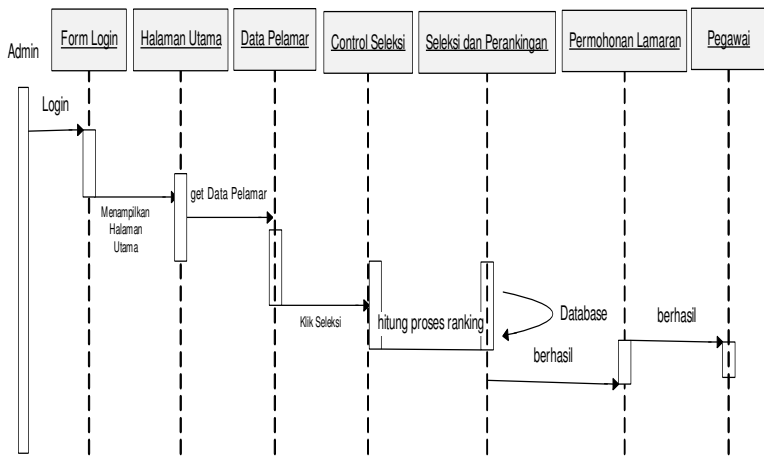

Gambar 3.9 Sequence diagram untuk use case seleksi

\subsection{ERD (Entity Relationship Diagram)}

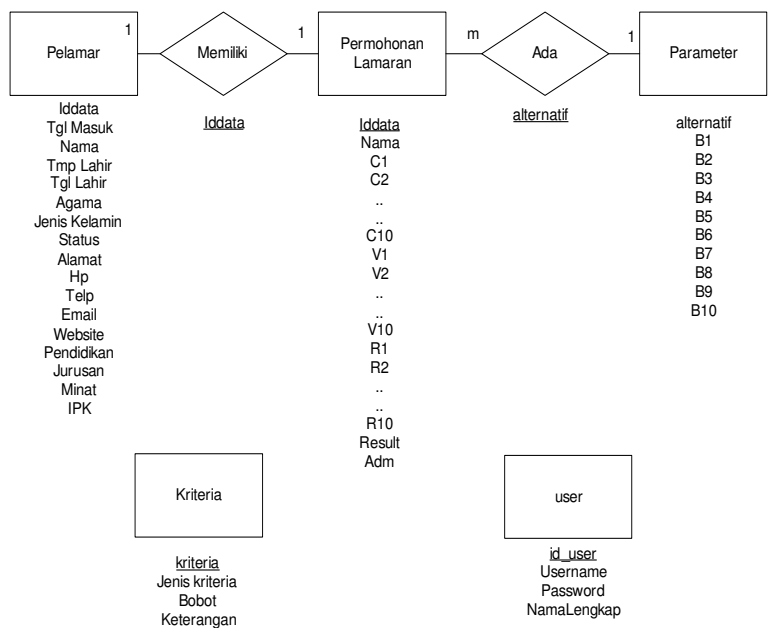

Gambar 3.10 ERD SPK penerimaan pegawai baru

\subsection{Class diagram}

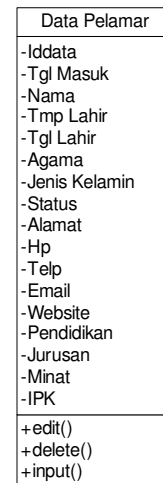
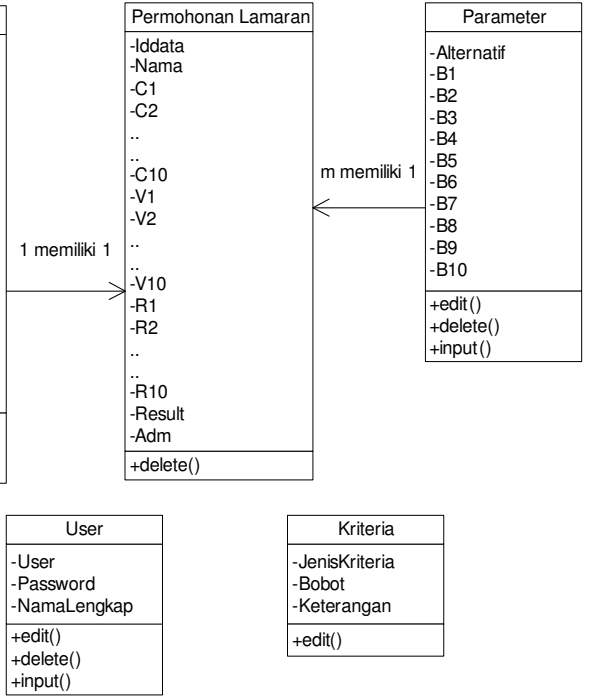

Gambar 3.11 Class Diagram SPK penerimaan pegawai baru

\subsection{Basis Data Spesifikasi}

a. Tabel Pelamar, untuk menyimpan .detail pelamar yang digunakan untuk proses ranking

$$
\begin{array}{ll}
\text { Nama Tabel } & \text { : Tabel Pelamar } \\
\text { Primary Key } & \text { : id_data }
\end{array}
$$

\begin{tabular}{|c|c|}
\hline Field & Jenis \\
\hline iddata & varchar(15) \\
\hline nama & varchar $(30)$ \\
\hline tmp_lahir & varchar(25) \\
\hline tgl_lahir & date \\
\hline agama & varchar(15) \\
\hline jenis kelamin & varchar(1) \\
\hline status & Warchativit) \\
\hline alamai & text \\
\hline$h p$ & warchan 15 y \\
\hline ceip & Warchar(25) \\
\hline emait & Watcharison \\
\hline website & varchar 50 ) \\
\hline pondiditan 49 ablos & Anathat 64 \\
\hline his: & 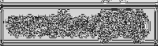 \\
\hline 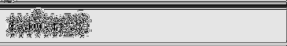 & 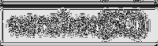 \\
\hline (56) & 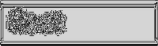 \\
\hline Tiljor & (6) \\
\hline (2) & (2) \\
\hline 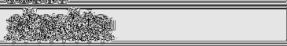 & 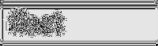 \\
\hline mordyry. & Now \\
\hline Propery & That: \\
\hline statedmintstast & Warohads \\
\hline 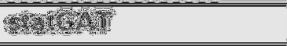 & Wratato \\
\hline startifine & varcha:(9) \\
\hline Sirresthom & 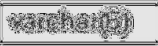 \\
\hline Statklessiehatan & *archaty \\
\hline
\end{tabular}

Tabel 3.2 Tabel Pelamar 
b. Tabel Bobotparam, untuk menyimpan bobot yang digunakan dalam perhitungan ranking dalam aplikasi ini.

Nama Tabel : bobotparam

Primary Key : criteria

\begin{tabular}{|l|l|}
$\begin{array}{c}\text { Tabel } 3.1 \text { Tabel } \\
\text { Field }\end{array}$ & \multicolumn{1}{|c|}{ Jenotparam } \\
\hline criteria & varchar(3) \\
\hline bobot & double \\
\hline keterangan & varchar(40) \\
\hline
\end{tabular}

c. Tabel Parameter, untuk menyimpan kriteria yang digunakan dalam perhitungan ranking dalam aplikasi ini.

Nama Tabel : Parameter

Primary Key : alternatif

Tabel 3.3 Tabel Parameter

\begin{tabular}{|l|l|}
\multicolumn{1}{|c|}{ Field } & \multicolumn{1}{|c|}{ Jenis } \\
\hline alternatif & $\operatorname{varchar(15)}$ \\
\hline c1 & $\operatorname{int}(2)$ \\
\hline c2 & $\operatorname{int}(2)$ \\
\hline c3 & $\operatorname{int}(2)$ \\
\hline c4 & $\operatorname{int}(2)$ \\
\hline c5 & $\operatorname{int}(2)$ \\
\hline c6 & $\operatorname{int}(2)$ \\
\hline c7 & int(2) \\
\hline c8 & int(2) \\
\hline c9 & $\operatorname{int}(2)$ \\
\hline c10 & $\operatorname{int}(2)$ \\
\hline cstat & int(1) \\
\hline
\end{tabular}

d. Tabel User, untuk menyimpan data-data user yang masuk ke dalam sistem.

Nama Tabel : User

Primary Key : id_user

Tabel 3.4 Tabel User

\begin{tabular}{|c|c|}
\hline Field & Jenis \\
\hline id_user & $\operatorname{int}(11)$ \\
\hline nama_lengkap & varchar(100) \\
\hline email & varchar(50) \\
\hline alamat & varchar(255) \\
\hline telepon & varchar(15) \\
\hline hp & varchorits \\
\hline 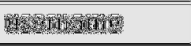 & 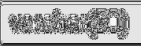 \\
\hline Hassuendit & 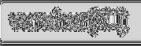 \\
\hline 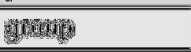 & 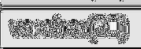 \\
\hline rastot & 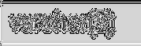 \\
\hline ôn & 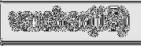 \\
\hline 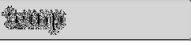 & 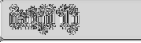 \\
\hline
\end{tabular}

\subsection{Statechart Diagram}

a. Statechart diagram login

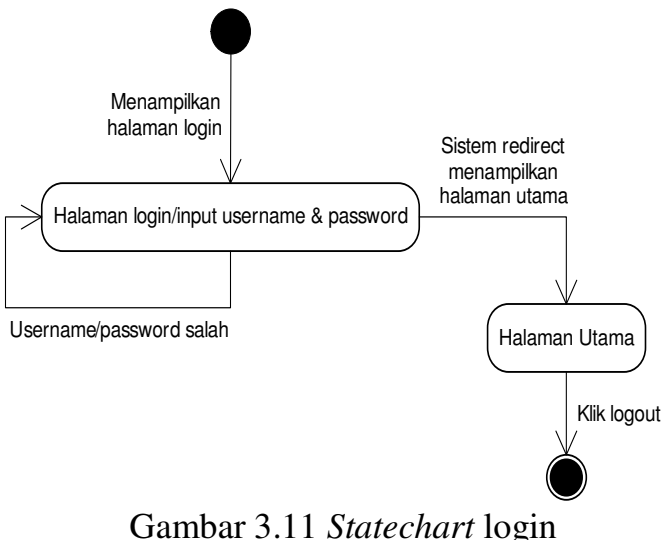

b. Statechart diagram data pelamar

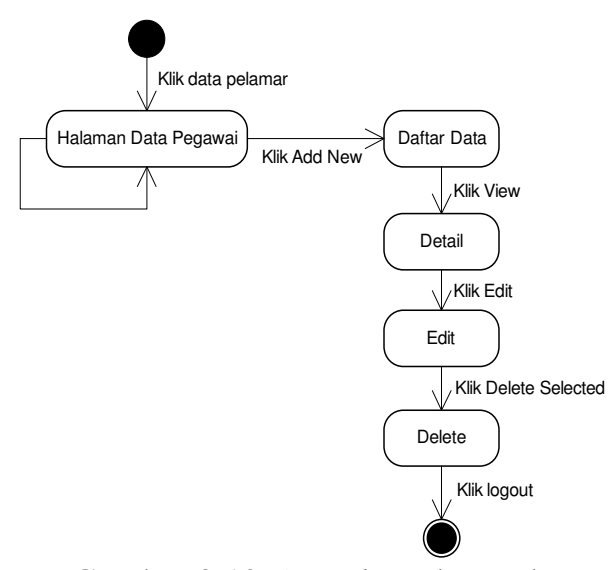

Gambar 3.12 Statechart data pelamar

c. Statechart diagram seleksi

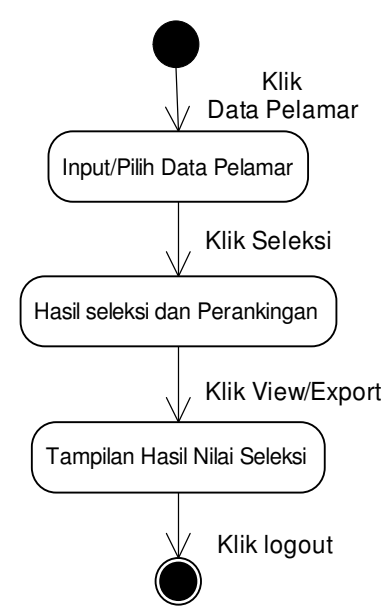

Gambar 3.13 Statechart seleksi 


\subsection{Component Diagram}

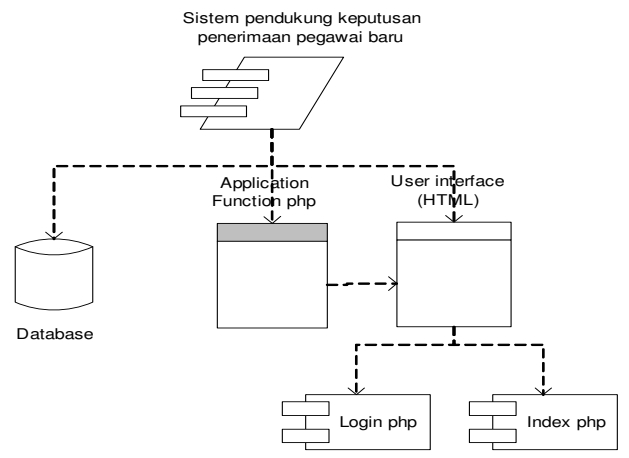

Gambar 3.14 Component Diagram SPK penerimaan Pegawai Baru

\subsection{Deployment Diagram}

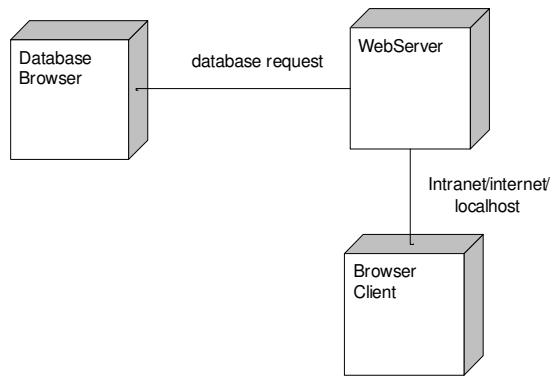

Gambar 3.15 Deployment Diagram SPK Penerimaan Pegawai Baru

\subsection{Hirarki Menu}

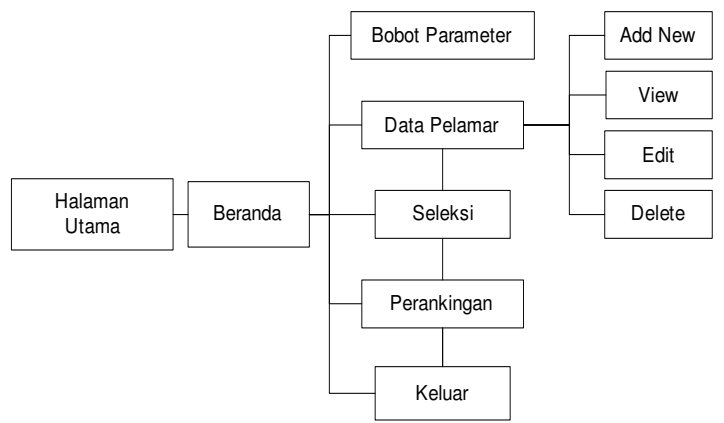

Gambar 3.16 Hirarki Menu SPK Penerimaan Pegawai Baru

\section{HASIL DAN UJI COBA}

\subsection{Hasil Rancangan Aplikasi}

Aplikasi dapat dibuka oleh user dengan mengetikkan pada web browser : http://localhost/saw/

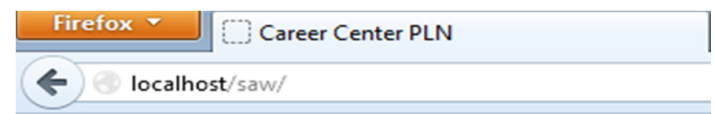

Gambar 3.17 Host Aplikasi Pada Web Browser

\subsubsection{Tampilan Login}

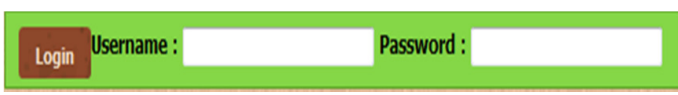

Gambar 3.18 Form Login

Pada gambar 3.18 form login merupakan tampilan untuk masuk kedalam aplikasi dengan melakukan input username dan password dengan benar. Kemudian klik login untuk masuk ke halaman utama. Apabila user salah dalam memasukkan username dan password maka akan muncul pesan kesalahan login seperti berikut :

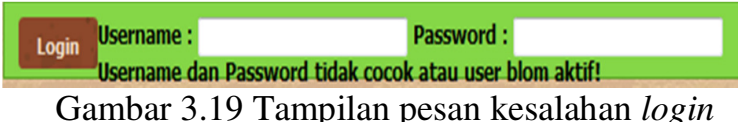

\subsection{Hasil Rancangan Pada User}

\subsubsection{Tampilan Halaman Beranda}

Gambar yang menunjukan tampilan ketika user masuk ke sistem aplikasi ini.

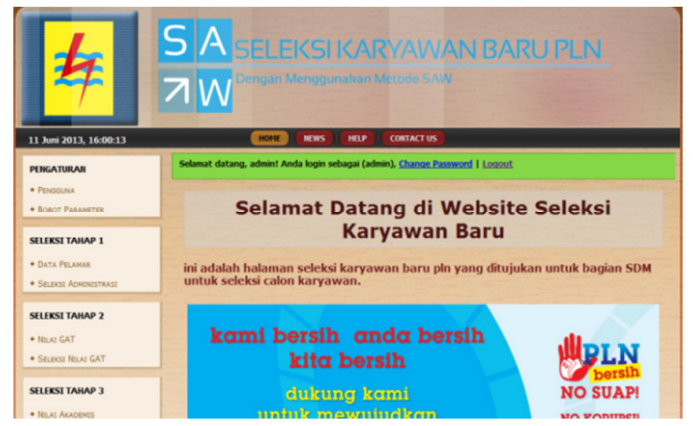

Gambar 3.20 Tampilan Beranda

Pada gambar 3.20 menunjukkan halaman utama ketika user masuk ke dalam sistem aplikasi penerimaan pegawai baru setelah menginput username dan password dengan benar pada proses login.

1. Tampilan Halaman Bobot Parameter

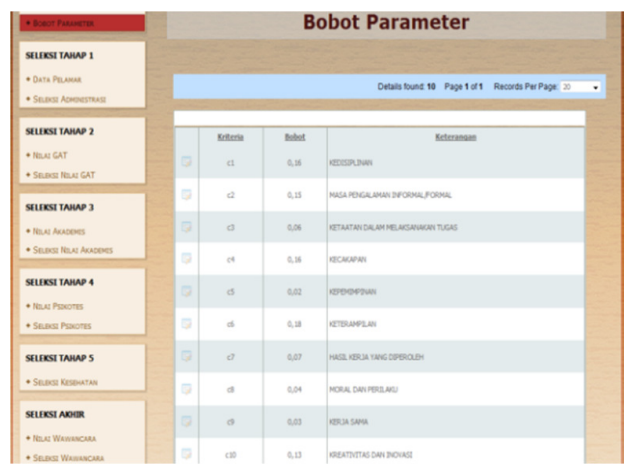

Gambar 3.21 Tampilan Halaman Bobot Parameter 
2. Tampilan Halaman Input Data Pelamar

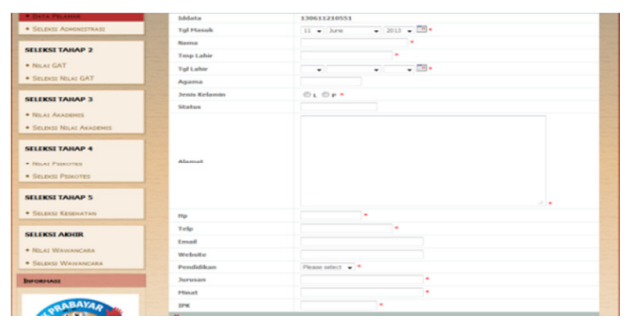

Gambar 3.22 Tampilan input data pelamar

Salah satu hak akses yang bisa dimilki oleh admin adalah input data. Admin dapat menambahkan data pelamar yang mengajukan permohonan lamaran pegawai yang selanjutnya akan diproses dalam perankingan.

\section{Tampilan Data Pelamar}

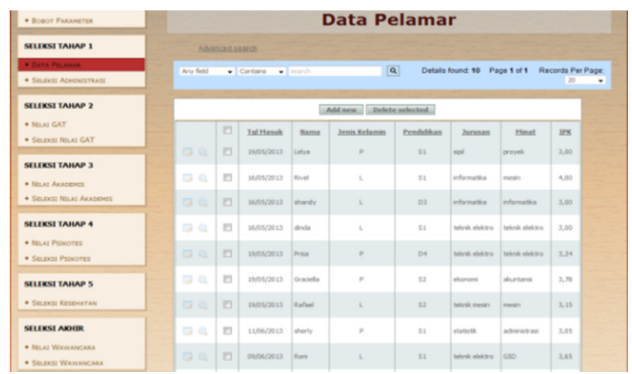

Gambar 3.23 Tampilan data pelamar

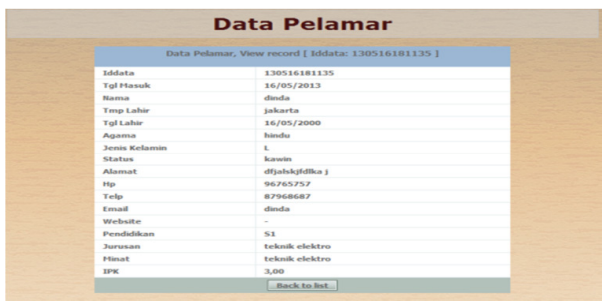

Gambar 3.24 Tampilan view data pelamar

4. Tampilan Seleksi

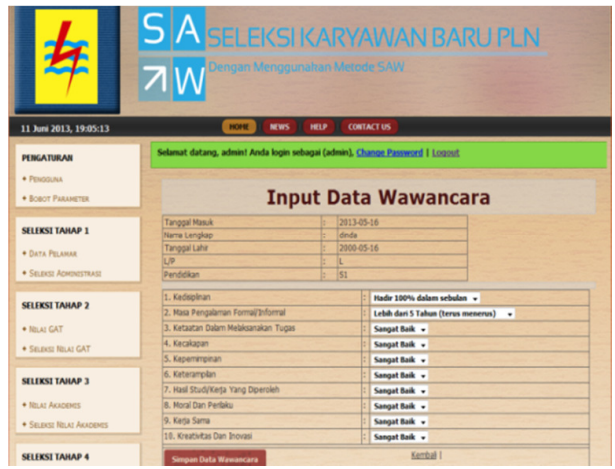

Gambar 3.25 Tampilan Seleksi

Pada gambar 3.25 menunjukkan inputan nilai yang akan diolah. Ada 10 kriteria yang akan diolah untuk dihitung dan menghasilkan hasil akhir yang bisa diranking.
5. Tampilan Hasil seleksi dan Perankingan

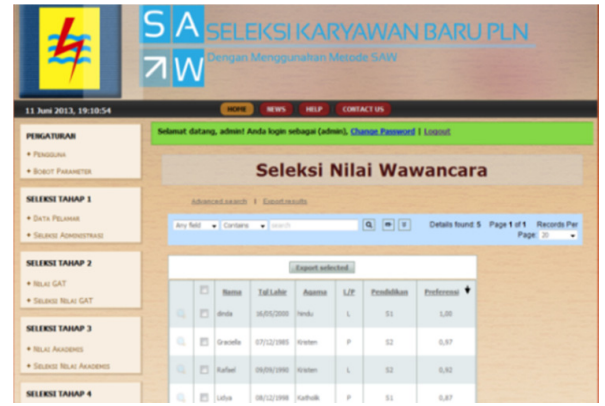

Gambar 3.26 Tampilan hasil seleksi dan perankingan

Pada gambar 3.26 menunjukkan hasil proses seleksi dan perankingan. Perankingan dapat diurutkan dari yang tertinggi sampai yang terendah dan sebaliknya. Dihalaman ini admin juga dapat melihat detail nilai masing-masing kriterianya.

\subsubsection{Pengujian Aplikasi}

1. Tujuan Pengujian Aplikasi

Pengujian aplikasi web ini menggunakan pengujian black box.

\begin{tabular}{|c|c|c|c|}
\hline No & $\begin{array}{c}\text { Form } \\
\text { Dan } \\
\text { Kondisi }\end{array}$ & Prosedur Uji Coba Sistem & Hasil \\
\hline 1. & $\begin{array}{c}\text { Login } \\
\text {-Kondisi } \\
1 \\
\text {-Kondisi } \\
2 \\
\\
\text {-Kondisi } \\
3\end{array}$ & $\begin{array}{l}\text {-Jika username dan password } \\
\text { tidak diisi / kosong, maka } \\
\text { aplikasi tidak dapat meng- } \\
\text { akses ke halaman utama. } \\
\text {-Jika salah satu dari } \\
\text { username atau password } \\
\text { tidak diisi / kosong maka } \\
\text { aplikasi tidak dapat meng- } \\
\text { akses ke halaman utama. } \\
\text {-Jika salah satu atau } \\
\text { keduanya dari username dan } \\
\text { password salah, maka } \\
\text { aplikasi tidak dapat meng- } \\
\text { akses ke halaman utama. }\end{array}$ & Berhasil \\
\hline 2. & $\begin{array}{c}\text { Data } \\
\text { Pelamar } \\
\text {-Kondsi } \\
1\end{array}$ & $\begin{array}{l}\text {-Jika data yang wajib diisi } \\
\text { pada form masih belum } \\
\text { terisi/kosong maka aplikasi } \\
\text { tidak dapat melakukan } \\
\text { penyimpanan data. }\end{array}$ & Berhasil \\
\hline 3. & $\begin{array}{l}\text { Seleksi } \\
\text { dan } \\
\text { perankin } \\
\text { gan } \\
\text {-Kondisi } \\
1\end{array}$ & $\begin{array}{l}\text {-Pada tahap seleksi ada } 9 \\
\text { tahapan yang harus dilaku- } \\
\text { kan. Jika salah satu tahapan } \\
\text { seleksi tidak terpenuhi maka } \\
\text { tidak dapat menlanjutkan } \\
\text { seleksi tahap berikutnya. } \\
\text { Seleksi ke } 10 \text { adalah metode } \\
\text { SAW, yaitu seleksi } \\
\text { wawancara. } \\
\text {-Jika } 9 \text { tahapan seleksi } \\
\text { diawal terpenuhi maka } \\
\text { proses seleksi akhir bisa } \\
\text { diproses dan dilanjutkan } \\
\text { dengan hasil perankingan. }\end{array}$ & Berhasil \\
\hline
\end{tabular}


2. Pembahasan Aplikasi

Aplikasi sistem pendukung keputusan yang dibuat saat ini dirancang untuk membantu pekerjaan bagian Seleksi dan Rekrutmen dalam hal pengelolaan , proses penyimpanan dan proses perankingan data pelamar. Pembuat keputusan akan dimudahkan dalam pengambilan keputusan dalam menentukan calon pelamar yang lulus seleksi menjadi pegawai. Penggunaan basis data pada aplikasi ini memudahkan dalam proses input, edit, dan delete, search bagi user, selain itu data yang ada menjadi tersusun dan berelasi dengan baik.

Aplikasi ini dibangun berdasarkan kemajuan teknologi yang sangat pesat. Tujuan perancangan aplikasi ini yaitu untuk mempermudah semua pihakpihak yang terkait di dalamnya. Aplikasi ini diharapkan mampu memudahkan semua pihak-pihak yang terkait terutama dalam input, pengolahan dan penyimpanan data pelamar untuk proses pengambilan keputusan penerimaan pegawai baru.

\section{KESIMPULAN}

Sistem Pendukung Keputusan yang dapat dibuat guna membantu membuat keputusan dalam penerimaan calon pegawai baru pada PT.PLN (Persero) Kantor Pusat berdasarkan hasil analisa sesuai dengan kriteria yang ditentukan. Penerimaan dilakukan sesuai dengan hasil seleksi Administrasi, General Aptitude Test (GAT), Akademis dan Bahasa Inggris, Psikotes dan FGD, Kesehatan dan wawancara yang dimiliki calon pegawai baru tersebut. Adapun kriteria yang telah ditentukan dalam tahap seleksi wawancara adalah Kedisiplinan (C1), Masa pengalaman informal/formal (C2), Ketaatan dalam melaksanakan tugas (C3), Kecakapan (C4), Kepemimpinan (C5), Keterampilan (C6), Hasil kerja yang diperoleh (C7), Moral dan perilaku (C8), Kerjasama (C9), Kreativitas dan inovasi (C10).

Model yang digunakan untuk sistem pendukung keputusan adalah model Multiple Attribute Decision Making (MADM) dengan metode Simple Additive
Weighting (SAW). Metode ini dipilih karena metode ini menentukan nilai bobot untuk setiap atribut, kemudian dilanjutkan dengan proses perankingan yang akan menyeleksi alternatif terbaik. Penelitian dilakukan dengan mencari nilai bobot untuk setiap kriteria, dan kemudian membuat proses peringkat yang akan menentukan alternatif yang optimal adalah pelamar terbaik. Hasil dari aplikasi sistem pendukung keputusan ini adalah terpilihnya alternatif terbaik pelamar yang berhak diterima menjadi pegawai karena lulus seleksi secara terurut sesuai perankingan.

\section{Daftar Pustaka}

[1] Kusrini. 2007. Konsep dan Aplikasi Sistem Pendukung Keputusan. Yogyakarta : Andi

[2] Turban, Efraim dan Jay E. Aronson, Ting-Peng Liang. 2005.Decision Support Systems and Intelligent Systems. Penerbit : Pearson/Prentice Hall

[3] McLeod, Raymond dan George P.Schell.2004. Sistem Informasi Manajemen. Terjemahan oleh Jakarta : Salemba Empat.

[4] O'Brien, James A.2011. Introduction to Information System. Penerbit: Pennsylvania State University

[5] Wibowo, Angga, 2006. Aplikasi PHP Untuk Pengembangan Web. Semarang; Penenerbit Andi.

[6] http://id.wikipedia.org/wiki/Perusahaan_Listrik_N egara

[7] http://indojobhunter.com/lowongan-kerja-bumnpt-pln-persero.html

[8] http://www.pln.co.id/

[9] http://ilmukomputer.org/

[10] http://yenikustiyahningsih.files.wordpress.com/20 13/04/spk-saw.pdf

[11] http://www.scribd.com/doc/45255336/MetodeSaw-Contoh-2 